SALAM; Jurnal Sosial \& Budaya Syar-i

FSH UIN Syarif Hidayatullah Jakarta

Vol. 7 No. 9 (2020), pp. 775-786, DOI: 10.15408/sjsbs.v7i9.15273

\title{
Maintaining Relationship Through Magibung Local Wisdom*
}

\author{
I Ketut Sudarsana ${ }^{1}$, I Nyoman Ananda ${ }^{2}$, Ni Nengah Selasih ${ }^{3}$, \\ I Made Suta ${ }^{4}$, Ni Gusti Ayu Agung Nerawati ${ }^{5}$ \\ Universitas Hindu Negeri I Gusti Bagus Sugriwa Denpasar, Bali, Indonesia
}

doI $\underline{10.15408 / \text { sjsbs.v7i9.15273 }}$

\begin{abstract}
The purpose of this study was to find the role of magibung in maintaining community relationships. The implementation of magibung in the belief system is one form of local wisdom in the middle of the Hindu community, especially in Bali. Magibung which is supported by the community through religious ceremonies is one way to strengthen relationships in the Hindu community. It does not only has an impact on the successful implementation of religious ceremonies but also unity and foster "meyama braya" attitude meyama braya.

Keywords : Tradition, Local Wisdom, and relationship in Hindu community
\end{abstract}

\begin{abstract}
Abstrak
Penelitian ini bertujuan untuk menemukan peranan kearifan lokal magibung dalam menjaga persaudaraan masyarakat. Pelaksanaan tradisi magibung pada sistem kepercayaan merupakan salah satu bentuk kearifan lokal di tengah masyarakat Hindu khususnya di Bali. Tradisi magibung yang didukung oleh masyarakat melalui kegiatan upacara keagamaan merupakan salah satu jalan untuk mempererat persaudaraan masyarakat Hindu. Hal ini tidak hanya berdampak pada suksesnya pelaksanaan upacara keagamaan, tetapi juga persatuan dan menumbuhkan sikap meyama braya.
\end{abstract}

Kata Kunci : Tradisi, Kearifan Lokal, dan Persaudaraan Umat Hindu

* Received: April 11, 2020, Revised: July 14, 2020, Published September 3, 2020.

${ }^{1}$ I Ketut Sudarsana is a lecturer at Universitas Hindu Negeri I Gusti Bagus Sugriwa Denpasar, Bali, Indonesia. E-mail : iketutsudarsana@ihdn.ac.id

${ }^{2}$ I Nyoman Ananda is a lecturer at Universitas Hindu Negeri I Gusti Bagus Sugriwa Denpasar, Bali, Indonesia.

${ }^{3} \mathrm{Ni}$ Nengah Selasih is a lecturer at Universitas Hindu Negeri I Gusti Bagus Sugriwa Denpasar, Bali, Indonesia.

${ }^{4}$ I Made Suta is a lecturer at Universitas Hindu Negeri I Gusti Bagus Sugriwa Denpasar, Bali, Indonesia.

${ }^{5}$ Ni Gusti Ayu Agung Nerawati is a lecturer at Universitas Hindu Negeri I Gusti Bagus Sugriwa Denpasar, Bali, Indonesia. 


\section{A. INTRODUCTION}

Indonesia is a country that is very rich in cultural, ethnic, ethnic, and racial diversity, where there are approximately 389 ethnic groups that have different customs, languages, values, and cultures. According to the Asian Brain "customs, values and culture govern some aspects of life such as social relations, worship rituals, beliefs, myths and traditional sanctions that apply in the environment of existing indigenous peoples"6. Regional cultural diversity is a social potential that can form its character and cultural image in each region and is an important part of forming the image and cultural identity of a region. Besides, diversity is intellectual and cultural property as part of cultural heritage that needs to be preserved.

Along with the improvement of technology and cultural transformation towards modern life and the influence of globalization, cultural heritage and traditional values of the community face challenges to its existence. This needs to be examined because the cultural heritage and traditional values contain a lot of local wisdom that is still very relevant to the current conditions, and should be maintained, adapted, or even further developed.

In the context of life, change is a necessity. The changes that occur are not only related to the physical environment but also human culture. The close relationship between humans and the physical environment forms tradition. Tradition is formed because of the ability of humans to get around the environment to remain worthy to be inhabited time after time. Tradition is seen as a manifestation of every person or community that is always changing and is the effort and struggle of each person or group in determining the future. Each region has a potential that needs to be developed. The potential possessed by each region varies greatly. The diversity of potentials needs special attention so that the next generation is very aware of the potential, values, and traditions of the region as local wisdom.

One of the diverse national cultures is Balinese culture which is inseparable from the static and dynamic character. With this static and dynamic character, there is a fundamental development in the era of globalization in the form of rapid social and cultural changes. The change occurred because of the progress of science and technology. The world is becoming narrower with increasingly sophisticated communications and transportation advancements. "Beginning with communication, interactions occur that result in new problems that need to be resolved. Technological progress is very influential in the life of the community, so that changes occur in the community, especially in developing community."7

In religious life, one of the real manifestations in supporting national culture is magibung. Magibung contains noble values and has the concept of togetherness better known as menyama braya in Bali so that prosperous community life and soul will be achieved. Magibung can then become a culture-based education media. According to

\footnotetext{
6 Asian Brain. "Suku Bangsa". dalam http://www.anneahira.com/indonesia/suku-bangsa.htm diunduh pada 4 September 2019.

${ }^{7}$ Koetjaraningrat. Kebudayaan, Mentalitas Dan Pembangunan. (Jakarta: PT Gramedia, 1974), h. 133
} 
Tabrani. ZA "Education is a cultural process to enhance human dignity and that lasts throughout life. Education is always developing and always faced with changing times. For this reason, inevitably education must be designed to follow the rhythm of change, if education is not designed to follow the rhythm of change, then education will lag behind the speed of the development of the era itself ${ }^{8}$.

Magibung is an ancestral heritage that is now still alive and developing during community life. As a distinctive tradition, magibung has been embedded in the hearts of the people so that it is still preserved.

\section{B. RESEARCH METHODOLOGY}

This study used a qualitative method. The qualitative study method is a study procedure that produces descriptive data in the form of written or spoken words from individuals, groups, or even observable behaviors. This study was included in a field study using several methods of data collection. First, observation. Second, in-depth interviews were conducted with the help of interview guidelines. Third, a literature review on the topic of study. Informants were determined by using the snowball technique, which means data were extracted through in-depth interviews from one respondent to another respondent, and so on until the researcher did not find new information anymore. The data were analyzed descriptively and qualitatively to provide a clear and objective description of the focus of this study. So, conclusions can be drawn according to the formulation of the problem under study.

\section{ANALYSIS AND DISCUSSION}

\section{The Survival of Magibung Tradition}

According to the Indonesian General Dictionary, survival originates from "survive" which means (1) remains in a state (position), not easily damaged (changed, lost, flexible, etc.), (2) strong or able to suffer (bear something), (3) can control yourself, (4) able; do not feel disgusted quickly ${ }^{9}$. Based on this, the survival referred to in this study is something that is fixed and does not change.

Tradition is an existing set of beliefs, practices, teachings, and modes of thinking that are inherited from the past and that may guide, organize, and regulate ways of living and of making sense of the world. The term comes from the Latin verb tradere, meaning to transmit or to give over. The noun tradition indicates the process by which something is transmitted or handed down. Gross depicts the central responsibility involved in tradition as receiving something valuable or precious, preserving it, and passing it on to those who come after. Tradition, however, is not merely preserved and passed down intact to subsequent generations. As traditions are handed down

\footnotetext{
${ }^{8}$ Tabrani ZA. Ilmu Pendidikan Islam (Antara Tradisonal dan Modern). (Kuala Lumpur: Al-Jenderami Press, 2009), h. 12

${ }^{9}$ Poerwadarminta. Kamus Lengkap Bahasa Indonesia. (Jakarta: Balai Pustaka, 1984), h. 991
} 
consecutively over time, they change because the relations that encompass a receiving generation are never the same as those of the transmitting generation ${ }^{10}$.

In this concept, the traditions or customs of a particular region may not necessarily be owned by other regions that have been passed on for generations. Related to this study, one of the good traditions which are still preserved is magibung. Magibung is a treat that is presented to guests when a community performs its panca yadnya. This tradition is held in East Bali and also in Badung, Gianyar, and Buleleng. In this context, the survival of magibung is something that has not changed or become extinct and still exists today.

\section{Local Wisdom}

Based on the English-Indonesian dictionary, local wisdom consists of two words, namely wisdom and local, which means values, local views that are wise, full of wisdom, of good value that are embedded and followed by members of the community. Anthropologically, local wisdom is known as a local genius. This local genius is a term that was first introduced by Quaritch Wales.

Anthropologists discussed the definition of local genius ${ }^{11}$. Haryati Soebadio stated that local genius is the national cultural identity or personality that causes the nation to be able to absorb and process foreign cultures according to their character and abilities ${ }^{12}$. Moendardjito stated that potential regional cultural elements can be said to be local geniuses because they have survived to the present time with the following characteristics; 1) able to withstand external culture, 2) can accommodate elements of outside culture, 3) can integrate external cultural elements into native culture, 4) can control, 5) able to give direction to the development of culture ${ }^{13}$.

Local wisdom is local knowledge that is created from the adaptation results of a community that comes from life experiences that are communicated from generation to generation. Local wisdom is local knowledge that is used by local communities to survive in an environment that is integrated with beliefs, norms, culture, and expressed in the traditions and myths that are held for a long time. "The process of regeneration of local wisdom is performed through oral traditions (folklore) and literary works, such as chronicles, suluk, song, saga, lontarak, and so forth"14.

According to Azkia Muharom Albantani and Ahmad Madkur "Local wisdom is defined as the local richness that contains policies or life viewpoints. Local wisdom serves with its function to shape human beings to be wiser in undergoing their lives. In Indonesia, local wisdom is not necessarily applicable within a local context or ethnic, but

${ }^{10}$ Yatta Kanu. Tradition and Educational Reconstruction in Africa in Postcolonial and Global Times: The Case for Sierra Leone. dalam African Studies Quarterly, Vol. 10, No. 3 (2007), h. 66

${ }^{11}$ Ayatrohaedi. Kepribadian Budaya Bangsa (local Genius). (Jakarta: Pustaka Jaya, 1986), h. 18

${ }^{12}$ Ayatrohaedi. Kepribadian Budaya Bangsa (local Genius). (Jakarta: Pustaka Jaya, 1986), h. 19

${ }^{13}$ Ayatrohaedi. Kepribadian Budaya Bangsa (local Genius). (Jakarta: Pustaka Jaya, 1986), h. 40

14 Restu Gunawan. "Kearifan Lokal dalam Tradisi Lisan dan Karya Sastra", Makalah Kongres Bahasa, 2008. 
cross-cultural or cross-ethnical natures as well, in the hope of establishing national cultural values"15. In this case, local wisdom in the whole regional or ethnic culture system that has long-lived and developed into a cultural element that must be nurtured and integrated into the new culture of the nation as a whole. The relevant and contextual survival of local wisdom has an important meaning for the development of a nation, especially when viewed from the point of survival of culture, besides having an important meaning for the identity of the region itself. Local wisdom with past cultural content is a milestone in the present life.

\section{The Survival of Magibung tradition}

Magibung is an activity of eating out together that involves many people and is related to traditional ceremonies in the community. Magibung has prominent characteristics such as religious, aesthetic, solidarity, sense of belonging, cooperation based on "tat twam asi" or humanity ${ }^{16}$. According to the Balinese-Indonesian dictionary, magibung is the activity of eating out together in a dish (rice and side dishes in one place). Gibungan is a meal or food that is eaten by eight people together by sitting in a circle ${ }^{17}$ (Kersten SVD, 1984).

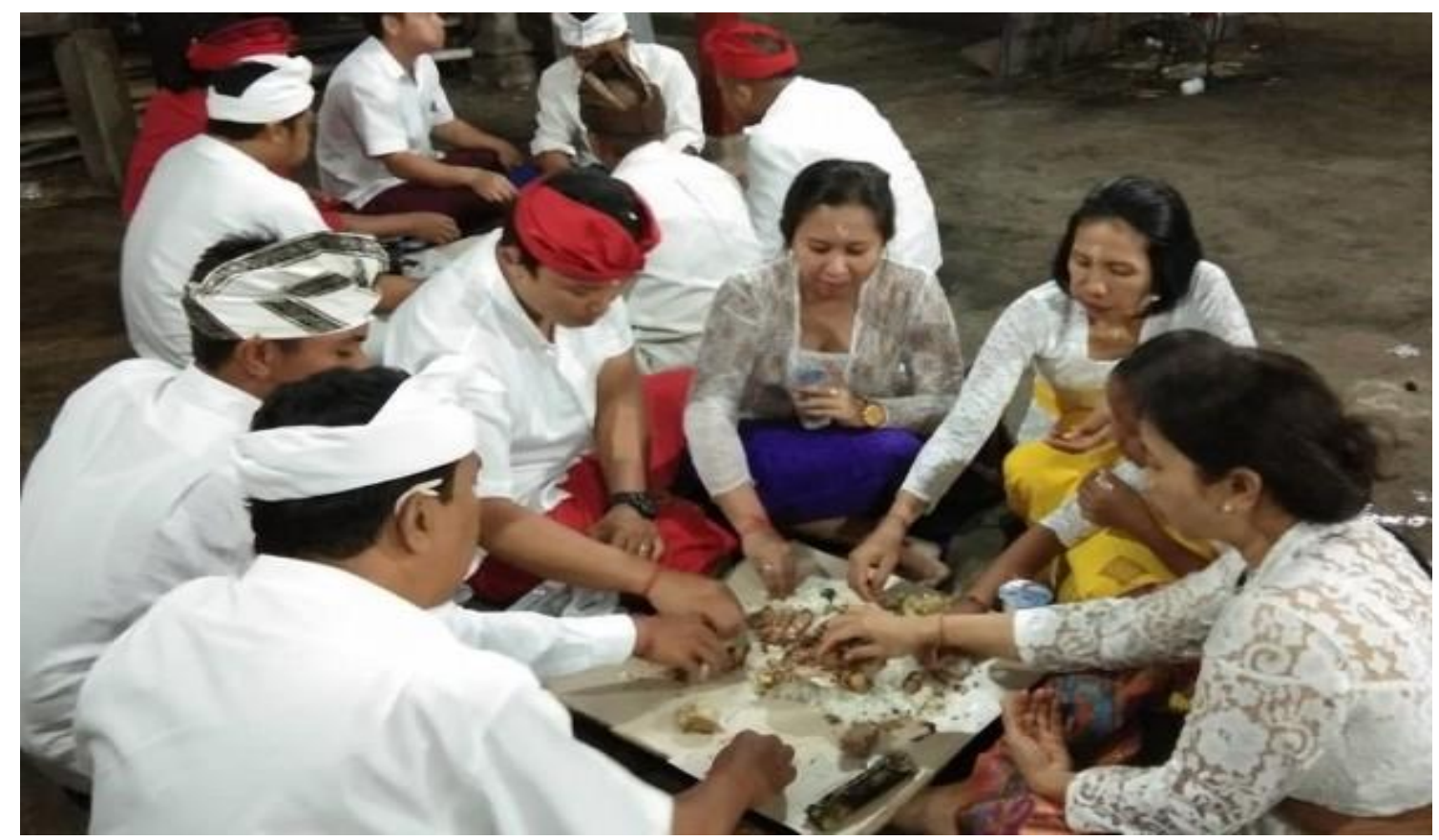

Figure 1. The procedures for magibung in Karangasem

(Source: https://bali.idntimes.com)

15 Azkia Muharom Albantani and Ahmad Madkur. Think globally, act locally: the strategy of incorporating local wisdom in foreign language teaching in indonesia, dalam International Journal of Applied Linguistics and English Literature, Vol 7, No 2 (2018), h. 1-8.

${ }^{16}$ Ida Bagus Mantra, Bali: Masalah Sosial Budaya, (Denpasar: Upada Sastra, 1990), h. 21

${ }^{17}$ J.Kersten S.V.D. Bahasa Bali (Tata Bahasa dan Kamus Bahasa Lumrah). (Ende Flores: Nusa Indah, 1984), h. 228 
Magibung is the activity of eight people eating together by sitting around a gibungan. Magibung "actually has many definitions. If the number of participants more than eight people it is also called magibung. Magibung is the pride of the East Bali community, where if one person carries out a religious ceremony both in the "nista", "madya" and "utama" categories, there is always a magibung. Magibung seems to have a pleasant nuance and can foster a high relationship, besides instilling manners.

Magibung is the actualization of culture and customs manifested concretely in the norm. Magibung is a community tradition that is preserved and passed on from the older generation to the younger generation. In the process, magibung changes. The development of magibung as a culture has never been avoided from contact with other cultures. "Through the development of global communication, interculturality has now become a limit. As a result, the orientation of customs and traditions to act singly from the original tradition, culture also undergoes a process of division into sub-variations"18.

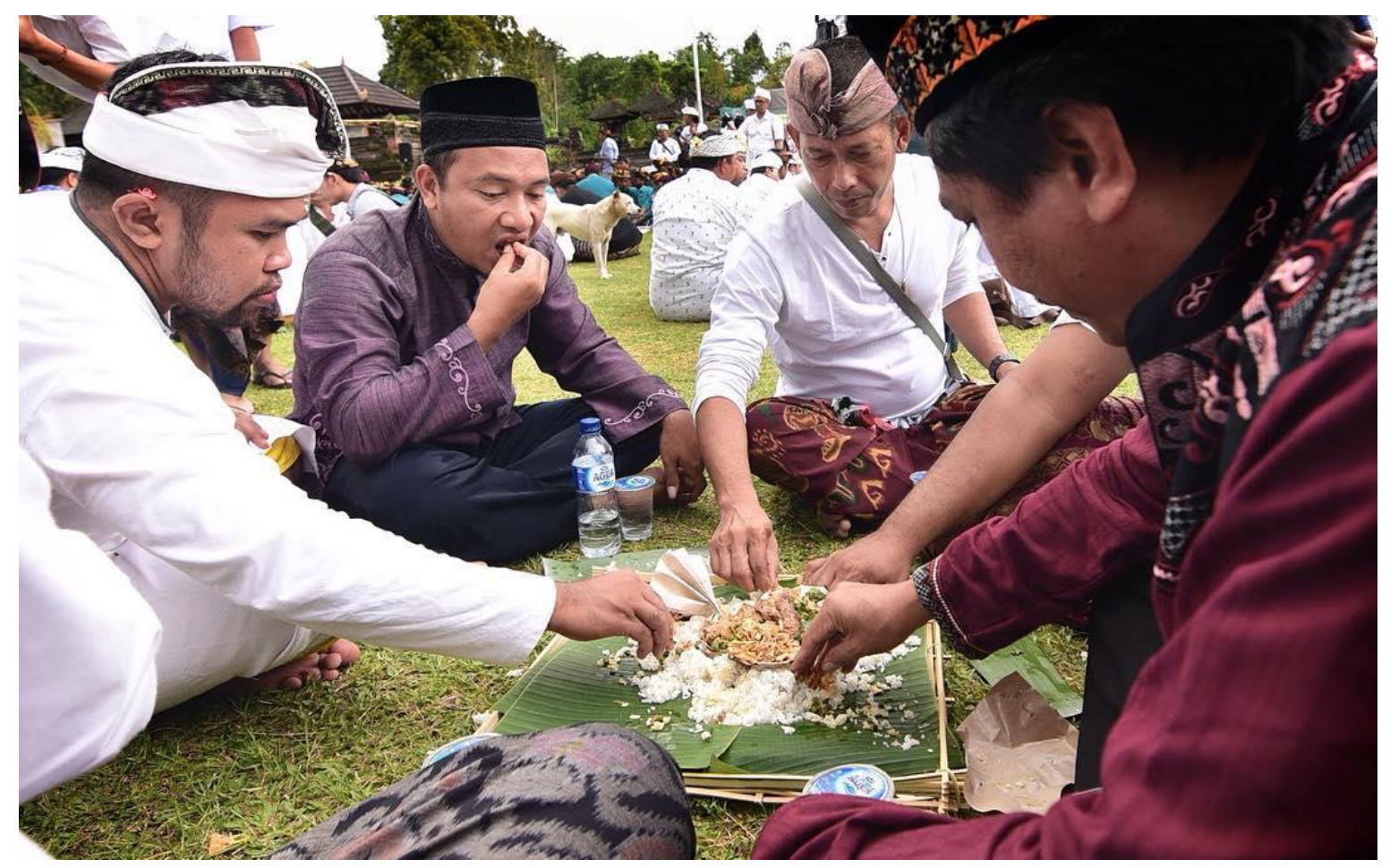

Figure 2. Magibung: Synergy 'Caring for Grassroots' in Kinship Circle

(Source: https://www.kulkulbali.co)

Magibung for the community is still alive and developing amid globalization, which is growing and advancing in line with the development of globalization. Magibung is not a difficult tradition, the participants can be done by anyone without recognizing the different degrees of good from the Brahmins, Kshatriyas, Vaishyas, and Shudras, including from the upper and middle-class community. The survival of magibung tradition is strongly influenced by the existence of Hindu ceremonies in Bali

18 Soehardi. Kekerasan Dalam Persfektif Budaya, Dalam Manusia dan Dinamika. (Yogyakarta: Universitas Gajah Mada, 2001), h. 7 
and the content of noble values and has a meaning of togetherness/tolerance known as menyama braya. In practice, before the magibung there are some preparations:

a. The place is cleaned and the mat is arranged according to the number of sela (groups).

b. Arranging gibungan following the number of sela (groups).

c. Providing drinking water and drinking glass.

d. Providing traditional drinks (palm wine and wine)

e. Provide hand washing water

f. Provide pengagang (magibung officers) to help magibung participants if there is a lack of rice, water, etc.

If already provided, magibung is commanded by one person who usually comes from a close relative as the organizer of the event or from a family representative who knows and understands magibung, so that magibung can take place following applicable procedures.

In practice, there are some rules in magibung, such as eating using the right hand, not using the left hand, not using a spoon or fork, sitting cross-legged, the left hand is on the lap, while the right hand is actively taking the dish, the place to eat should not close to klakat (place of gibungan). Rice and side dishes that have been grasped are pulled out of the mouth and let the rest (kribisan) fall on the lap. Kribisan (leftovers) are prohibited from falling on klakat, because it makes other magibung participants offended. Likewise, when bones or food scraps that are about to be bitten, the remaining bites should not be put back into klakat (place of gibungan). The rest of the food must be disposed of in front of the lap. When drinking, the tip of the kettle should not touch the lips and by sucking. Water is allowed to run into the mouth. For those who are not accustomed, a glass for drinking has been prepared instead. Apart from that what needs to be considered in magibung is that participants must not leave other participants even though they are full (wareng). After completing, participants wash their hands and leave the place of gibungan.

Magibung may seem difficult, but on the other hand, those who are accustomed to doing it have a pleasant meaning where a high sense of brotherhood will emerge. There are several ways that can be performed in magibung. Residents or invitees who attend, if given the command by the penua (the oldest) to go to the place of gibungan, immediately move and make a group of eight people. If it is complete, must wait for the next command to wait nuunang (the first meal) onto the rice.

Men with men as well as women and women. Formally, they are no mixing of men and women. Although there are a husband and wife who follow the reception or kundangan in magibung the two must separate. Men and women are separated despite the status of husband and wife and if they come together in an event, participants magibung do not have to know each other. In a magibung, all the participants are regarded as equal, in the sense that all the differences are based on soroh (genealogical bloodline), clan, and wangsa (social standing based on one's occupation) are disregarded. Therefore, 
when the participants of the magibung are invited by the organizers of the karya (event), spontaneously they go to the gibungan that has been provided.

Magibung participants must not take or stand before the other magibung participants finish. Magibung participants do not finish when the banquet is over, but when the organizer of the event gives a pancanagan (in the form of betel, pamor, gambier, mako, and so on). In its development, many communities no longer do mamak (eat a betel), so that it is replaced with cigarettes. After the magibung is finished, participants are invited to ngadeg (stand up) and can only dismiss after receiving a command from the pengayah (officers).

In terms of the equipment used, magibung is still traditional, this is certainly very interesting for tourists who come to Bali. Because in terms of togetherness, this certainly contains a very broad understanding, because the magibung system will create relationships which in Balinese are known as meyama braya.

Magibung has a very deep meaning and is one of the local wisdom that must be maintained. Local wisdom (local genius) is the truth that has been steady in a region. Local wisdom is a combination of religious holy values and various existing values. Local wisdom is formed as the cultural excellence of the local community and geographical conditions. Local wisdom is a product of the past culture that deserves to be constantly held on to life. Although it is local, the value it contains is considered to be very universal.

\section{Magibung As Local Wisdom In Maintaining Relationship Of Hindu Community}

Aside from being local wisdom, magibung is the implementation of manusia yadnya. In panca yadnya, several sections explain the provision of food to the community, one of them is in satapatha brahmana that manusia yadnya is offering food to others. In rorawa srama panca, manusia yadnya is interpreted as giving. The implementation of panca yadnya in Lontar Agastya Parwa mentioned that manusia yadnya is providing food to the community.

Magibung as an ancestral heritage that is now still alive and developing can be said to be a characteristic of Hindu community, because in every religious ceremony activity, if without magibung then it is incomplete, besides that magibung also becomes part of the Hindu religious ceremony itself. To emphasize the position of tradition, Manawadharmasastra XII.95. stated that:

Ya vedahyah smrtayo

Yas ca kasca kudrstaya

Sarvatasnisphala pretya

Tamo nistha hi ta smrtah $^{19}$ (Pudja \& Sudharta, 2002)

${ }^{19}$ Gde Pudja \& Tjok Rai Sudharta, Manawa Dharmasastra (Manu Dharmasastra). (Jakarta: CV. Felita Nusantara Lestari, 2002), h. 57 
Translation:

All traditions in the philosophical system that are not sourced from the Vedas will not reward them after death, because they are stated to have originated in the darkness.

The effort to maintain magibung is not only the task of the government but also the task of the whole community because the culture is a guide for the community in behaving and carrying out life. The preservation of magibung depends on the appreciation of the community on local wisdom. With a high appreciation of the culture, then the effort to preserve culture will be easily carried out.

Conversely, the lower the appreciation of the community, the more difficult the effort to preserve the culture. Thus, the most important effort in the preservation of a culture is to increase the appreciation of the community for culture and this is certainly a pretty heavy effort is carried out individually. However, if efforts to raise culture are carried out jointly and in a coordinated way, it is not impossible that efforts to preserve various cultures will not meet any significant obstacles. Likewise in social life, the Hindu community prioritizes togetherness such as magibung which is held by the family by involving all adolescents to adulthood, so that it can become an activity that educates the community directly about actions that are social education, arts, and culture, ethics and moral discipline. in life so that it can lead to an improvement in life.

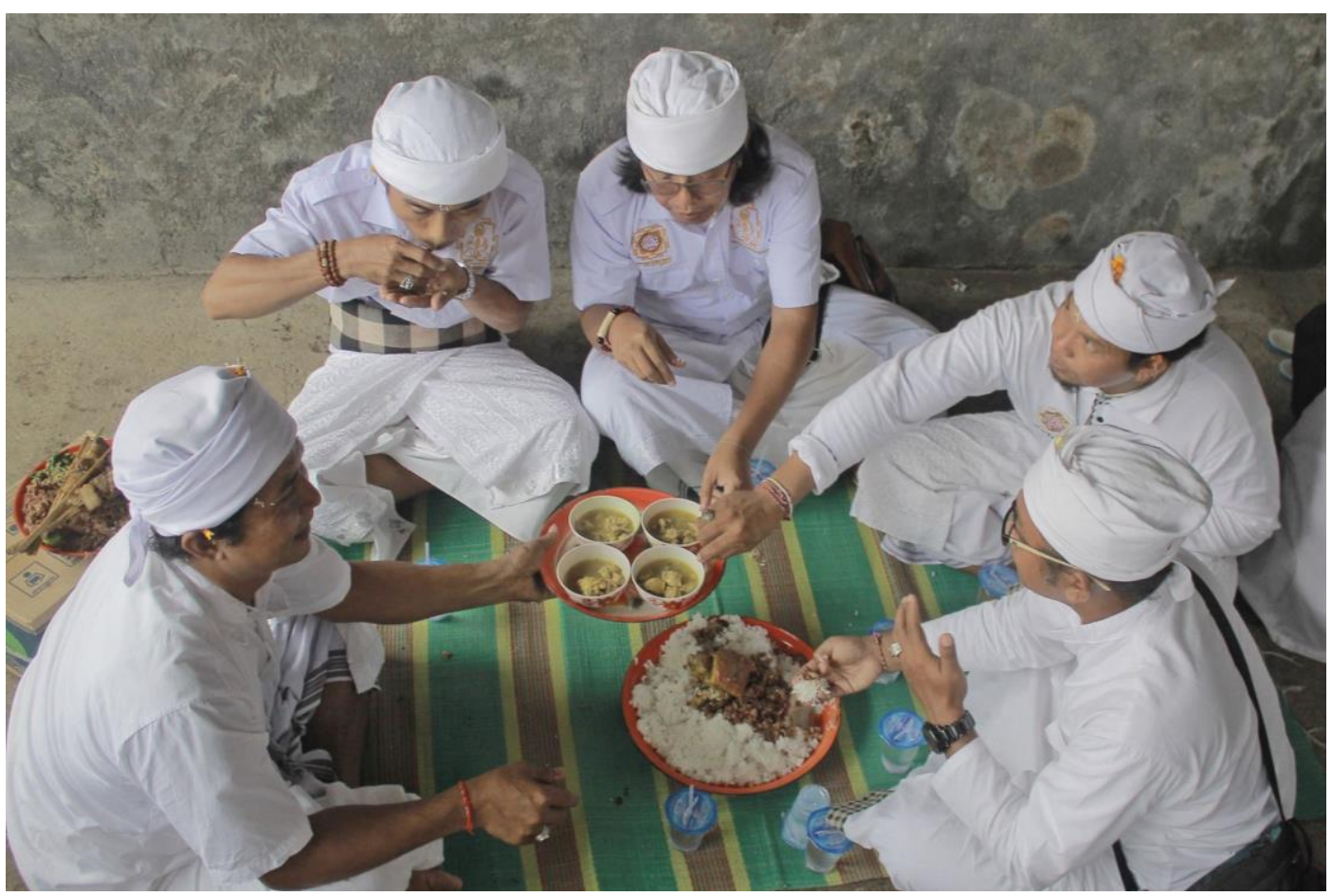

Figure 3. Magibung

(Source: https://dictionary.basabali.org)

Magibung as Balinese local wisdom contains a spirit of brotherhood and a sense of social solidarity which includes two things: 1) the formation of personality and 2) the formation of social behavior. Both work in harmony and balance. No matter how good 
the personality of someone if they are not able to explain in the life of the community, then it does not belong to the category of social solidarity. Vice versa, so that the quality of individuals and social behavior one must respect others. The moral is the same as having a spirit of social solidarity. Humans can not have the same outlook on life or opinion. The difference is a necessity. The difference that occurs in each community is a gift. The task of humans is how to shape the differences into a beautiful and harmonious togetherness.

For the Bali community, especially those who still uphold ancestral cultural values, brotherhood is not limited to what is said in words but is manifested in concrete actions when some families or neighbors ask for help. The socio-cultural solidarity values prioritize the existence of close kinship that is far from emphasizing material or physical. These forms of relationship are still visible in many villages. Magibung is a tradition of eating out together on the sidelines of a yadnya ceremony or salvation ceremony in the region as a reflection of how socio-cultural solidarity values should be built among fellow communities.

The values of brotherhood through the magibung inherited from the ancestors to the next generation are still relevant to be implemented in the present stage of life. The order of brotherhood values provides a reference to how the best behavior is to control oneself and interact with each other and among the environment. These values make a positive contribution to realizing the creation of prosperity and the progress of the nation. Values are beliefs that make a person act on the choices. While brotherhood is essentially the attitude of the same boat, sympathy, and loyal among fellow communities.

Magibung as local wisdom is needed for the creation of order, peace, justice, politeness, welfare, science, education, value system development, institutional development, conflict prevention, and behavior change. There are social norms that uphold peace, togetherness, and cooperation. Local wisdom can be interpreted as good cultural values that exist in a community. If someone wants to know local wisdom, one must be able to understand good cultural values. The values of local wisdom have been taught from generation to generation by parents to their children.

The culture of cooperation, a sense of brotherhood, and mutual respect are small examples of local wisdom. Custom is tested naturally and has good value because the habit is a repetitive and reinforced social act. If an action is not considered good by the community then it will not experience continual reinforcement.

\section{CONCLUSION}

A theory by Malinowski on community solidarity and integration confirms that a nation, especially a small community, is driven by a principle called the principle of reciprocity, which is the principle of giving which gives rise to the obligation to retaliate. That principle is the motivation of magibung in various fields of community life, including the fields of religion and beliefs. This principle serves to maintain solidarity and integration in a shared life as a community. 
Magibung as local wisdom upholds the values of brotherhood and togetherness so that a sense of belonging can be realized in the life of the Hindu community. The impact of the implementation of magibung on the harmony of Hindu life in Bali has provided an exclusive image of the community itself.

\section{REFERENCES}

Albantani, A. M., \& Madkur, A. (2018). Think globally, act locally: the strategy of incorporating local wisdom in foreign language teaching in Indonesia. International Journal of Applied Linguistics and English Literature, 7(2), 1-8., 7(2), 1-8.

Ayatrohaedi. (1986). Kepribadian Budaya Bangsa (local Genius). Jakarta: Pustaka Jaya.

Brain, A. (2010, September 04). 'Suku Bangsa'. Diambil kembali dari Anneahira: http://www.anneahira.com/indonesia/suku-bangsa.htm

Gunawan, R. (2008). Kearifan Lokal dalam Tradisi Lisan dan Karya Sastra. Makalah Kongres Bahasa, (hal. 28-31).

Kanu, Y. (2007). Tradition and Educational Reconstruction in Africa in Postcolonial and Global Times: The Case for Sierra Leone. African Studies Quarterly, 65-84.

Kersten SVD, J. (1984). Bahasa Bali (Tata Bahasa dan Kamus Bahasa Lumrah). Ende Flores: Nusa Indah.

Koetjaraningrat. (1974). Kebudayaan, Mentalitas Dan Pembangunan. Jakarta: PT Gramedia.

Mantra, I. B. (1990). Bali: Masalah Sosial Budaya. Denpasar: Upada Sastra.

Poerwadarminta. (1984). Kamus Lengkap Bahasa Indonesia. Jakarta: Balai Pustaka.

Pudja, G., \& Sudharta, T. R. (2002). Manawa Dharmasastra (Manu Dharmasastra). Jakarta: CV. Felita Nusantara Lestari.

Soehardi. (2001). Kekerasan Dalam Persfektif Budaya, Dalam Manusia dan Dinamika. Yogyakarta: Universitas Gajah Mada.

Tabrani. (2009). Ilmu Pendidikan Islam (Antara Tradisonal dan Modern). Kuala Lumpur: AlJenderami Press. 
I Ketut Sudarsana, I Nyoman Ananda, Ni Nengah Selasih, I Made Suta, Ni Gusti Ayu Agung Nerawat 